\title{
Sadimo digitalno - projekt digitalne eko škole*
}

\author{
Mario Dumančić \\ Učiteljski fakultet u Zagrebu \\ Savska cesta 77, 10000 Zagreb \\ mario.dumancic@gmail.com
}

\author{
Tihana Levar \\ Osnovna škola "Jure Kaštelana" \\ Vladimira Ruždjaka 2a, 10000 Zagreb \\ tihana.levar@gmail.com
}

\author{
Mirena Maljković \\ Osnovna škola "Jure Kaštelana" \\ Vladimira Ruždjaka 2a, 10000 Zagreb \\ mirena.saric@yahoo.com
}

\section{Sažetak}

U akcijskom istraživanju provedenom kroz projekt Sadimo digitalno - projekt digitalne eko škole promatrali smo kako uvođenje novih tehnologija utječe na učenje i podučavanje. Projekt je realiziran kroz spoj suvremenih tehnologija i standardnih sadržaja iz aktualnog Nastavnog plana i programa. U projektu je ostvarena vertikalna suradnja između učenika drugog, četvrtog i šestog razreda i učiteljica informatike, prirode, geografije i razredne nastave. Kroz različite je aktivnosti realizirana i horizontalna suradnja između više nastavnih predmeta. Cilj je projekta usporediti rast i razvoj biljke graha koji se zalijevao ručno s onim zalijevanim uz pomoć Micro:bita, senzora vlažnosti tla i pumpe za zalijevanje te prezentirati zaključke, analize i rezultate dodatnih istraživanja. Kroz sve faze projekta učenici su uz pomoć učitelja osmišljavali aktivnosti vezane uz projekt, surađivali, istraživali i rješavali nastale poteškoće. Tijekom rada učenici su usmjeravani na pravilnu uporabu informacijsko-komunikacijskih tehnologija. Za potrebe projekta kreirane su i web stranice na kojima su objavljeni učenički radovi, prezentacije i dojmovi učenika o aktivnostima i zapažanjima koje su uočili.

Ključne riječi: IKT; STEM; Micro:bit; Vertikalna suradnja u osnovnoj školi.

\section{Uvod}

\subsection{Pristup poučavanju}

U digitalnoj eri u kojoj živimo ne treba posebno naglašavati važnost implementacije IKT-a u nastavu već od samih početaka obrazovanja naših učenika. Kredu i ploču zamjenjuju suvremene tehnologije, a učitelj više nije jedini izvor informacija ponuđen današnjem učeniku. Dok učenici uče činjenice bez razumijevanja njihovih uzročno posljedičnih veza ili primjene, istovremeno provode više vremena uz uređaje nego u socijalnoj interakciji s drugima. Vrijeme provedeno za tabletom ili pametnim telefonom često je bez smisla i svrhe. Usmjeravanje pravilnog korištenja novih tehnologija, poticanje učenika na istraživanje, razvijanje novih vještina

* Članak je prihvaćen za izlaganje na 20. CARNET-ovoj korisničkoj konferenciji CUC, 2018, Šibenik, Croatia 
te uvođenje suvremenijih metoda i sredstava za rad, rješenje je koje se nameće kao jedini odgovorni pristup u obrazovanju novih generacija (Beauchamp, 2017). Stoga je za učitelja nužno naučiti kako podučavati koristeći informacijskokomunikacijske tehnologije, istovremeno mijenjajući svoj pristup podučavanju.

\subsection{IKT u učenju za buduća zanimanja}

Današnjeg učenika potrebno je motivirati za samoučenje $i$ stalno usavršavanje te ga na taj način pripremati za buduća zanimanja. Kako tehnologije napreduju, tako se mijenjaju i poslovi koje djelatnici obavljaju. Radnik treba biti spreman i sposoban mijenjati se ili sam biti inicijator promjena na tržištu rada. Jedna od vještina koja je nužna za uspješan rad jest spremnost na suradnju na svim razinama uz poštivanje autoriteta te osobnosti i kvaliteta svakog kolege. Kako će učitelj pripremiti budućeg radnika za 21. stoljeće i odraditi taj odgovaran zadatak ovisi o njemu i njegovoj spremnosti za samoučenjem i suradnjom (Matijević, Topolovčan, 2017).

Jedno od rješenja za razvoj navedenih vještina radi učinkovitog osposobljavanja učenika za život jest provedba projekata. Sudjelovanje učenika u projektu na neki način simulira situacije u kojima će se budući zaposlenik nalaziti: planiranje, prilagođavanje situaciji, nailaženje na poteškoće, suradnja, traženje rješenja i niz drugih predviđenih i iznenadnih okolnosti na koje će naići u svome radu (Matijević, Topolovčan, 2017).

\section{Razrada}

\subsection{Akcijsko istraživanje}

Kroz projekt Sadimo digitalno provedeno je akcijsko istraživanje o utjecaju uvedenih digitalnih tehnologija u sadržaje iz aktualnog Nastavnog plana i programa odnosno predmetnih kurikuluma više nastavnih predmeta. U projektu su sudjelovali učenici drugog, četvrtog $i$ šestih razreda uz mentorstvo i suradnju učiteljica razredne nastave, geografije, prirode $i$ informatike. Time je tijekom provođenja svih etapa projekta, uz međupredmetnu korelaciju, ostvarena i izvrsna vertikalna povezanost učenika i učiteljica razredne i predmetne nastave.

\subsection{Cilj akcijskog istraživanja}

Cilj akcijskog istraživanja bio je uvesti u standardne teme Nastavnog plana i programa novi element, rad s Micro:bitom i promatrati kako će učenici reagirati na uvođenje suvremenijih metoda implementiranih $u$ postojeće nastavne sadržaje. Pored toga, svrha je ovog istraživanja kroz spoznavanje sadržaja nastavnih tema $u$ različitim razredima, postizanje vertikalne $i$ horizontalne suradnje.

Uvodeći novi način zalijevanja graha željeli smo učenicima predstaviti i nove načine praćenja rasta biljke te mogućnosti prezentiranja rezultata projekta i vezanih sadržaja koristeći informacijsko-komunikacijske tehnologije.

\subsection{Od ideje do realizacije}

Aktivnosti smo provodili sukladno opisima nastavnih predmeta Priroda i društvo i Priroda iz predmetnih kurikuluma koji, između ostalog, navode: „Iskustvena, istraživački usmjerena i problemska nastava u kojoj je učenik u središtu procesa učenja osigurava njegovu aktivnu ulogu u učenju i poučavanju. Prikupljanjem, obradom i prikazivanjem podataka te primjenom različitih oblika tehnologije razvijaju se informacijska, komunikacijska i digitalna pismenost" (MZO, 2017a). Učenici u jednostavnim istraživanjima razvijaju sposobnosti opažanja, postavljanja pitanja, oblikovanja pretpostavki, donošenja zaključaka i izvješćivanja o rezultatima usmjeravajući in na učinkovito i sigurno korištenje novim tehnologijama (MZO, 2017b).

$\mathrm{U}$ četvrtom je razredu tema u Nastavnom planu i programu Život biljke. Učenici kroz nju uče razlikovati glavne dijelove biljke. Jedan je od zadataka saditi grah i pratiti njegov rast. $U$ petom razredu kroz teme Biljka cvjetnjača-sjemenka (klijanje), korijen, stabljika, list, cvijet i plod-građa $i$ uloga te Uzgoj i zaštita biljaka $i$ životinja na nastavi prirode učenici produbljuju znanja o 
biljkama. Kroz sadnju graha praktično spoznaju o uvjetima klijanja, građi i ulozi dijelova biljke, zaštiti biljaka, tlu i gnojidbi. Prateći rast graha proučavaju njegov razvoj i strukturu.

Stoga je bilo logično projektom sadnje graha povezati učenike razredne i predmetne nastave $\mathrm{i}$ realizirati vertikalnu suradnju kroz koju učenici viših razreda sudjeluju u poučavanju učenika nižih razreda. Jedan je od najefikasnijih načina učenja, kako pedagozi ističu, onaj u kojem učenici uče jedni od drugih. Profesor učenja i podučavanja, dr. Charles Kivunja u svom radu Teorijske prespektive o učenju Digitalnih domorodaca (org. Theoretical Perspectives of How Digital Natives Learn) (Kivunja, 2014) naglašava kako je kooperativno učenje učinkovitije i omogućuje bolje obrazovne rezultate nego samostalno ili natjecateljsko učenje. Autor ističe kako bi se trebale iskoristiti prednosti digitalnih tehnologija kojima Digitalni domoroci svakodnevno komuniciraju i iskoristiti ih za prikazivanje nastavnih sadržaja na zanimljiviji način. Horizontalna se suradnja ostvarivala kroz različite aktivnosti iz više nastavnih predmeta u nižim i višim razredima (Ivers, 2009). Uz uvođenje Micro:bita u svrhu zalijevanja biljke, većina je aktivnosti povezana jednom temom ostvarivana digitalno.

Kao novi element $u$ nastavne teme iz aktualnog Nastavnog plana i programa uveli smo održavanje biljke Micro:bitom i pripadajućom opremom. Spremno smo prihvatili poziv za sudjelovanje u edukativno-ekološkom projektu izdavačke kuće Profil Klett MICRO:BIT: Programiranje i praćenje razvoja biljaka i osmislili školski projekt kroz koji će učenici postojeće propisane nastavne sadržaje spoznavati na novi, drugačiji način. Od izdavačke kuće dobili smo dodatnu opremu, senzor za mjerenje vlažnosti tla te pumpicu koju Micro:bit, ovisno o vrijednostima na koje smo ga programirali, aktivira i zalijeva biljku.
Osim zalijevanja biljke uz pomoć Micro:bita, u provođenje projekta uveli smo praćenje rasta biljke, aktivnosti međupredmetne korelacije i prezentiranje rezultata rada kroz IKT alate i programe. Uz mnogobrojna učenička digitalna ostvarenja, pitali smo ih i o dojmovima o sudjelovanju u projektu.

Kako je od ove godine u Republici Hrvatskoj u velikom zamahu opremanje škola Micro:bitom koje predvodi Institut za razvoj i inovativnost mladih - IRIM u suradnji s Carnetom i MZO u sklopu projekta ProMikro prvenstveno za učenike šestih razreda osnovnih škola, ovakav je projekt bio odličan način da Microbit nađe svoj put i u razrednu nastavu, dok je učenicima šestih razreda prikazano korištenje Micro:bita na vrlo konkretan i praktičan način.

\subsection{O Micro:bitu}

Micro:bit je džepno programibilno računalo koje omogućava kreativnost digitalnim tehnologijama. ${ }^{1}$

Micro:bit sadrži sljedeće tehničke karakteristike: 25 programibilnih LED lampica, 2 programibilne tipke, PINove za spajanje drugih uređaja, senzore za temperaturu i svjetlo, senzor za pokret (akcelometar i kompas), mogućnost bežične komunikacije kroz Bluetooth ili radio kanal te USB interface (Micro:bit Educational Foundation, 2018).

"BBC micro:bit je uzbudljiva nova tehnologija koju su razvili BBC, Microsoft i drugi partneri upravo s ciljem masovne uključenosti u osnovnim školama, ne samo u STEM području, nego i u dizajnu, umjetnosti i ostalim predmetima. Radi se o tehnologiji izrazito malih ulaznih barijera za koju je već razvijen bogati edukacijski sadržaj" (IRIM, 2018).

\footnotetext{
${ }^{1}$ Više na: http://microbit.org/hr/code/
} 


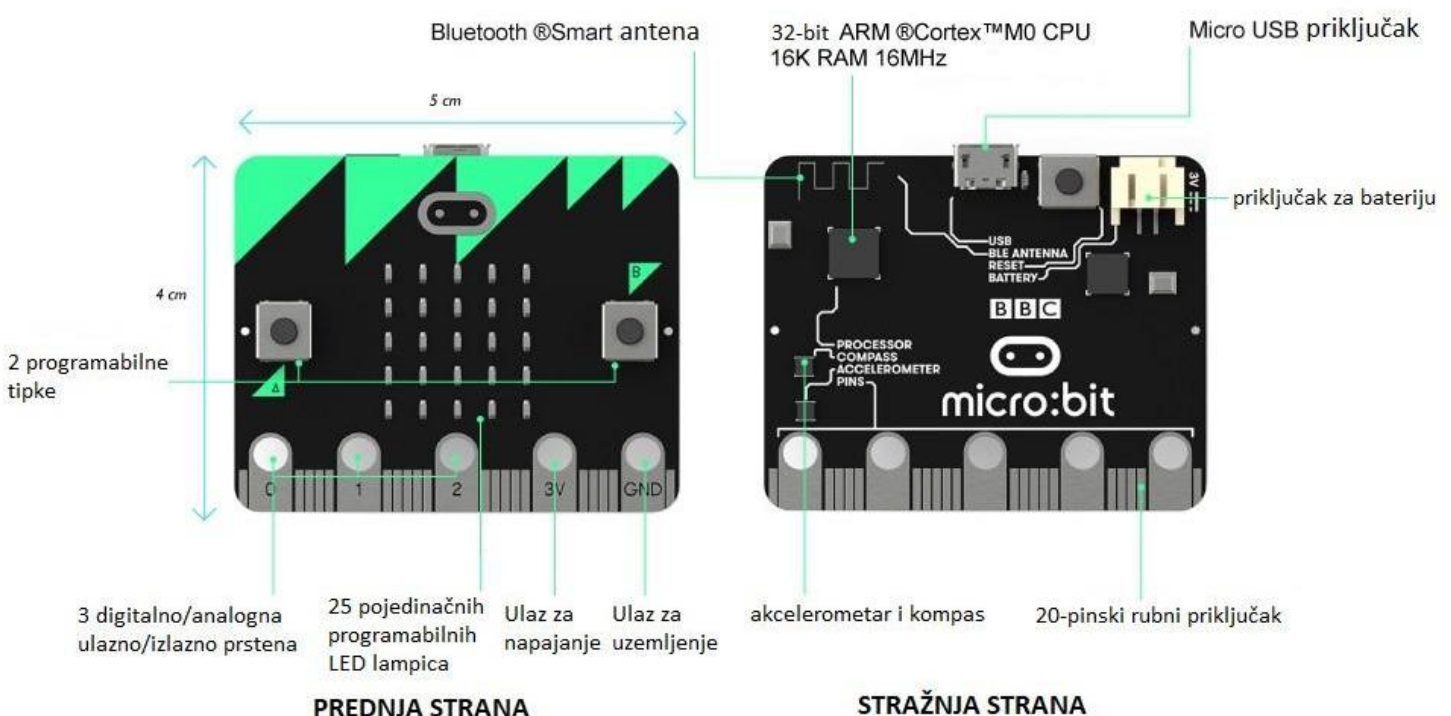

Slika 1. Shematski prikaz Micro:bita

\subsection{Provedba projekta}

Provedba projekta započela je suradnjom učiteljica informatike $i$ razredne nastave koje svojom vizijom već godinama postojeće nastavne sadržaje učenicima predstavljaju na zanimljiviji način, prateći suvremene tehnologije (Beauchamp, 2017). Učenici već od prvog razreda OŠ koriste informacijsko-komunikacijske tehnologije, a kroz ovaj su projekt učili istraživajući o korištenju novih. Za sve aktivnosti nije trebalo čekati provedbu kurikularne reforme. Ona se događa u našim učionicama. Odgovoran učitelj odgovarat će na zahtjeve društvenih promjena kako bi nastavne sadržaje približio učenicima.

Kako bi projekt imao veću dimenziju, bio interdiscipliniran te time učenicima zanimljiviji, $u$ projekt se uključilo još nekoliko entuzijasta: učiteljica razredne nastave u četvrtom razredu, učiteljica kemije i biologije (prirode) i učiteljica geografije te učenici drugog, četvrtog i šestog razreda.
Za ovaj su projekt kreirane weebly web ${ }^{2}$ stranice $s$ opisom, praćenjem i rezultatima projekta.

Kako naša škola ima status Međunarodne eko škole čiji se djelatnici trude učenicima usaditi elemente brige o svom okolišu, odlučili smo za sadnju upotrijebiti stare glinene posude kojima smo dali novo ruho. To su učinili učenici četvrtog razreda koji su decoupage tehnikom uredili tegle za sađenje.

Budući da je prema Nastavnom planu i programu Prirode i društva u četvrtom razredu predviđena sadnja graha, učenicima četvrtih razreda pripao je taj zadatak. Odabrali smo četiri sorte graha kako bismo usporedili rast graha različitih vrsta: trešnjevca, zelenčeka, balona $\mathrm{i}$ tetovca. $U$ jednoj tegli su posađene sve četiri sorte. $U$ tri je tegle posađen trešnjevac: jedna je zalijevana ručno, druga je gnojena, a treću je zalijevao uređaj pomoću Micro:bita. Zbog važnosti vertikalnog povezivanja učenici šestih razreda su učenicima drugih i četvrtih razreda objasnili što se i kako sadi, koji su uvjeti rasta biljke te kako o njoj brinuti. Nakon priprema tegli i sadnje graha, učenici drugih razreda preuzeli su

\footnotetext{
${ }^{2}$ Više na: https://www.weebly.com
} 
brigu o njegovom zalijevanju. Kako su biljke bile u njihovoj učionici, kreirali su tablicu zaduženja onih koji zalijevaju grah, redara koji paze na tegle, biljke i uređaj te onih koji svakodnevno fotoaparatom bilježe napredak rasta biljke. Istovremeno su učenici šestih razreda programirali Micro:bit te postavili uređaj za zalijevanje. Oni su u programu Office 365 također imali tablicu s terminima za kontrolu biljaka i ispravnosti uređaja te su u tablicu unosili zapažanja o rastu biljke. U One Drive mapu su redovito postavljali fotografije kojima su dokumentirali rast.

Zbog brzog rasta graha, uz pomoć školskog domara intervenirali smo i postaviti mu dodatnu potporu. S biljkama koje su ručno zalijevane nije bilo nikakvih poteškoća i projekt se odlično odvijao. Tim koji je motrio Micro:bit nije imao toliko sreće jer je u nekoliko navrata zakazala tehnologija. Prvobitni problem je nastao zbog nepravilnog programiranja Micro:bita. Trebalo je postaviti prave parametre za zalijevanje kako biljka ne bi bila previše ili premalo zalijevana. Taj je dio učenicima upravo donio i najviše uzbuđenja. Jedan je učenik šestog razreda primijetio kako je „to baš pravi pokus jer moramo puno puta isprobavati i pogriješiti dok napokon ne uspijemo". Zadovoljstvo kod konačnog uspjeha u programiranju je velika pozitivna strana ovakvog načina provođenja projekata $s$ učenicima. Nakon prve poteškoće dogodila se i druga. Uređaj, odnosno pumpica, prestala je raditi. $U$ rješavanje te poteškoće uključio se ravnatelj, profesor fizike i tehnike, koji je nakon uloženog znanja, vremena i truda popravio kvar na pumpici.

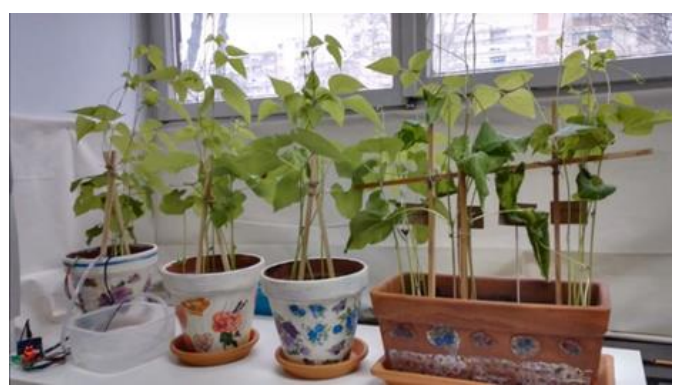

Slika 2. Stabiljke graha
Kako je rast biljaka tekao prema planu, bilo je važno na zanimljiv način pokazati rezultate projekta. U tu su svrhu učenicima održane kratke edukacije kroz koje su im prikazani i ponuđeni različiti programi i web alati. Koristeći te alate učenici su prezentirali rast biljke i rezultate popratnih istraživanja poput podrijetla graha $\mathrm{i}$ tijeka pripreme ukusnog jela, a za ponavljanje spoznavanih sadržaja izradili su online kvizove $i$ edukativne igre.

\section{Zaključak}

\subsection{Postizanje cilja}

Cilj akcijskog istraživanja kojeg smo proveli u formi projekta bio je uvesti novi element u već poznate nastavne sadržaje te pratiti dojmove učenika. Uvođenjem Micro:bita u održavanje biljke u klasičan smo način spoznavanja nastavnih sadržaja implementirali tehnologiju koju su učenici koristili u praćenju rasta i razvoja biljke, prezentacijama i izvještaju projekta.

Digitalnim domorocima, kako je današnju generaciju djece nazvao M.Prensky, nužno je ponuditi sadržaje i alate kojima ćemo im odgojno obrazovni proces učiniti zanimljivijim i učinkovitijim. Piaget je koncipirao učenje kao stalan proces interakcije između učenika i okoline što smo ovim projektom realizirali. Profesor učenja i podučavanja sa sveučilišta UNE, Charles Kivunja, koji je tradicionalne pedagogije uspoređivao s načinom funkcioniranja Digitalnih domoroca, zaključio je da djeca uče najbolje kad su sami uključeni u izgradnju svog znanja (Kivunja, 2014).

Osim što smo uveli nove tehnologije $u$ postojeće nastavne sadržaje, podučili smo učenike $\mathrm{i}$ motivirali ih za primjenu drugačijih metoda rada te razvijali međurazrednu i međupredmetnu suradnju.

Kako je već navedeno, mnogi su pedagozi naglašavali važnost kooperativnog učenja. Takav oblik učenja u njima razvija odgovornost prema skupini, potiče znatiželju za etape projekta te uvelike utječe na pozitivan ishod rezultata projekta (Vygotsky, 1978). Učeći s drugima, 
učenik razvija i dodatne vještine poput odgovornosti prema grupi i projektu, suradnju i toleranciju. Međupredmetno povezivanje, $s$ druge strane, daje širu sliku i omogućava da se kroz projektno spoznavanje nastavnih sadržaja sagledava cijela slika, čime je učinak nastave u obrazovnom smislu daleko veći. Učenicima se ne cjepkaju nastavni sadržaju i ne odvajaju nužno po nastavnim predmetima pokazujući im kako nijedna tema nije jednodimenzionalna. Učenje nije svrha samome sebi već je izuzetno važno da učenik nakon spoznavanja nastavnih sadržaja ovlada temom na razini njene primjenjivosti $u$ svakodnevnom životu.

Usmjeravanje na pravilnu uporabu IKT-a važan je dio ovog projekta koji je u potpunosti ostvaren.

\subsection{Rezultati rada}

Tijek provedbe projekta učenici su bilježili svakodnevnim fotografiranjem i dnevnicima zapažanja. Video uratkom prikazan je tijek rasta graha od sadnje do ploda. Učenici nižih razreda vodili su Dnevnik zapažanja koristeći tablicu u učionici, a učenici viših razreda tablicu u Office-u 365. Uz bilježenje rasta biljke učenici su izrađivali i dodatne sadržaje u korelaciji s ostalim nastavnim predmetima. Produkt toga su animirani film, Put jednog graha, memorijske igre u IKT i analognoj izvedbi, prezentacija o podrijetlu i svojstvima graha u Prezi prezentaciji; način rasta i sadnje graha u Animaker prezentacijama; adaptaciju priče Janko i grah te video o postupku kuhanja i degustaciji graha.

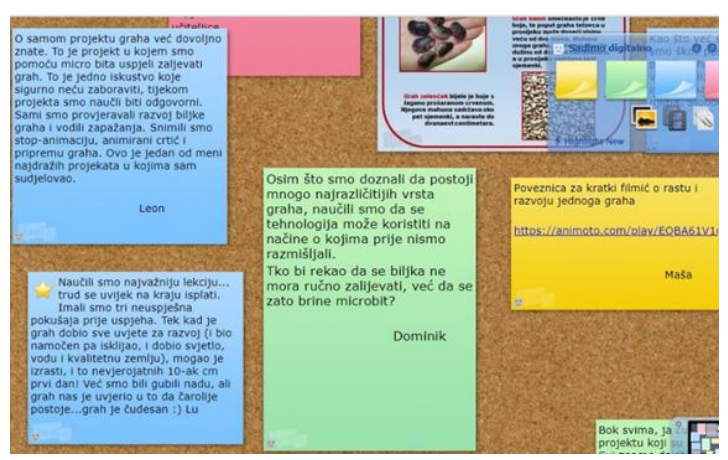

Slika 3. Učenički dojmovi
Učenički radovi napravljeni su na klasičan način i uporabom IKT-a. Ističemo kako su učenici samostalno odabirali sadržaj i njegov način predstavljanja čime su razvijali samostalnost, timski rad i ovladavanje novim alatima. Rezultat takvog načina vođenja projekta je visoka intrinzična motivacija i interes učenika za temu koji su utjecali na viši stupanj ovladavanja nastavnim sadržajima te proširenju znanja i izvan granica onoga što se mora znati.

Učenici su dojmove upisivali na online Linoit pano (Sadimo digitalno, 2018a), a svi rezultati rada prikazani su na mrežnim stranicama projekta (Sadimo digitalno, 2018b).

\section{Literatura}

Beauchamp, G. (2017). Computing and ICT in the primary school: from pedagogy to practice, Second Edition. London; New York: Routledge, Taylor \& Francis Group.

IRIM (2018). Zašto BBC micro:bit? Preuzeto 23. 4. 2018. sa http://croatianmakers.hr/hr/stemrevolucija.

Ivers, K. S. (2009). A teacher's guide to using technology in the classroom. Westport, Conn: Libraries Unlimited.

Kivunja, C. (2014). Theoretical Perspectives of How Digital Natives Learn. International Journal of Higher Education, 3(1), 94-109.

Matijević, M., Topolovčan, T. (2017). Multimedijska didaktika. Zagreb: Školska Knjiga.

Micro:bit Educational Foundation (2018). Meet micro:bit. Preuzeto 23. 4. 2018. sa http://microbit.org/guide/.

MZO (2017a). Nacionalni kurikulum nastavnog predmeta Priroda i društvo. Preuzeto 22. 4. 2018. sa https://mzo.hr/sites/default/files/do kumenti/2017/OBRAZOVANJE/NACION-KURIK /PREDMETNI-KURIK/priroda_i_drustvo.pdf.

MZO (2017b). Nacionalni kurikulum nastavnog predmeta Priroda. Preuzeto 22. 4. 2018. sa 
https://mzo.hr/sites/default/files/dokumenti/ 2017/OBRAZOVANJE/NACION-KURIK/PREDME TNI-KURIK/priroda.pdf.

Sadimo digitalno (2018a). Sadimo digitalno. Preuzeto $24 . \quad 4.2018 . \quad$ sa http://linoit.com/users/Kastelan/canvases/Sa dimo\%20digitalno.

Sadimo digitalno (2018b). Sadimo digitalno: Prezentacije radova. Preuzeto 27. 4. 2018. sa https://sadimodigitalno.weebly.com/prezenta cije-radova.html.

Vygotsky, L. (1978). Mind in Society: The development of higher psychological process. Cambridge, MA: Harvard Universtiy Press.

\section{Planting Digitally - Project of a digital environmental school}

of computer and communication technologies. For the purposes of the project web pages were also designed featuring pupils' works, presentations and impressions about the activities and observations.

Keywords: ICT; STEM; Micro:bit; Vertical collaboration in elementary school.

\begin{abstract}
In the action research conducted within the Planting Digitally Project of a digital environmental school we have observed the way introducing new technologies affects learning and teaching. The project was realized through a combination of modern technologies and standard contents from the current Curriculum. This project has achieved a vertical cooperation between the second, fourth and sixth grade students and teachers of computer science, natural science, geography and classroom teaching. Through various activities, horizontal cooperation between several teaching subjects has been realized. The aim of the project is to compare the growth and development of the bean plant that was watered manually with the one watered using Micro:bit, soil moisture sensor and watering pumps, and to present conclusions, analysis and the results of further research. Through every stage of the project pupils, with the help of their teachers, devised project-related activities, collaborated, investigated and solved difficulties they encountered. In the course of their work pupils were directed towards the proper use
\end{abstract}

